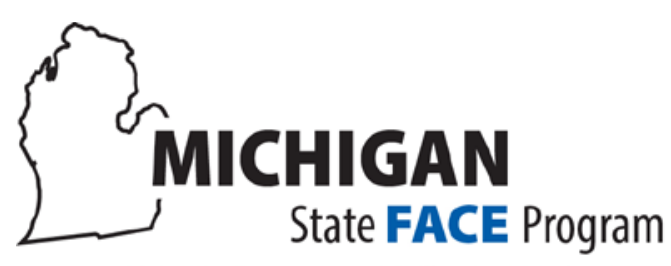

Fatality Assessment \& Control Evaluation

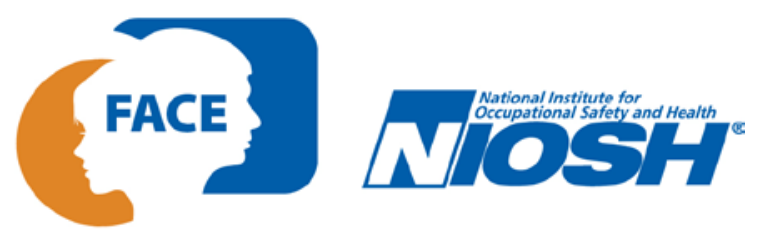

Michigan State University

Department of Medicine - Occupational and Environmental Medicine

909 Fee Road, 117 West Fee Hall • East Lansing, MI 48824 • 1-517-353-1846 • https://oem.msu.edu

INCIDENT HIGHLIGHTS

DATE:

Fall, 2017

TIME:

1:36 p.m.

VICTIM:

Construction foreman In his 40s

INDUSTRY/NAICS CODE:

Construction/23

EMPLOYER:

Roofing Contractor

SAFETY \& TRAINING:

Fall Protection, Aerial Lift

SCENE:

Pole Barn

LOCATION:

Michigan

EVENT TYPE:

Fall

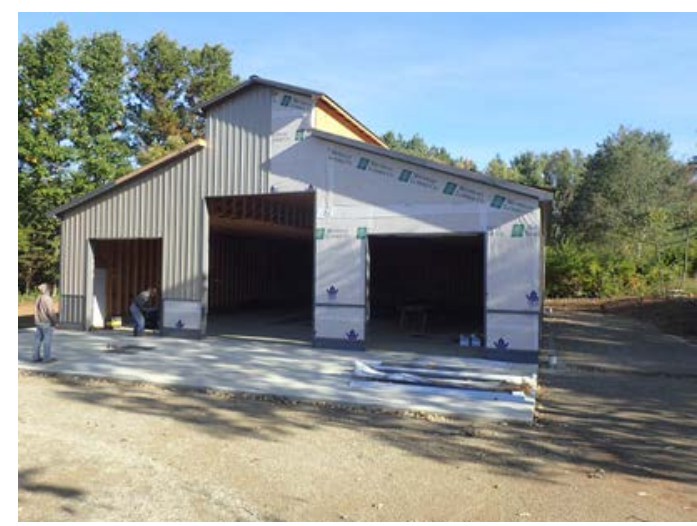

REPORT\#: 17MI128

REPORT DATE: 8/5/19

\section{Construction Foreman/Carpenter Dies from Complications From Fall From Roof}

\section{SUMMARY}

In fall 2017, a male construction foreman/carpenter in his 40 s died from complications from a fall from a pole barn roof. The decedent was accessing the roof from a lift that was positioned so he could step from the lift to the roof. He was not wearing fall protection. The decedent was holding onto a sheet of plywood as he stepped from the lift to the roof, to hand the plywood to a coworker who had accessed the roof using a 25-foot ladder. The decedent took a few steps backward and may have stepped on the wet metal sheeting.... $\underline{\text { READ }}$ THE FULL REPORT> (p.3)

\section{CONTRIBUTING FACTORS}

Key contributing factors identified in this investigation include:

- Decedent did not wear fall protection

- Did not take work/environmental conditions into account

o Stepped from lift to roof holding OSB board during $12 \mathrm{mph}$ winds

o Metal roof was wet

$\underline{\text { LEARN MORE }>(p .7)}$

\section{RECOMMENDATIONS}

MIFACE investigators concluded that, to help prevent similar occurrences, employers should:

- Ensure that at least one of the following is used whenever employees are exposed to a fall of 6 feet or more above a lower level: Guardrail Systems; Safety Net Systems; Personal Fall Arrest Systems.

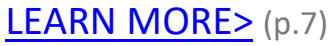




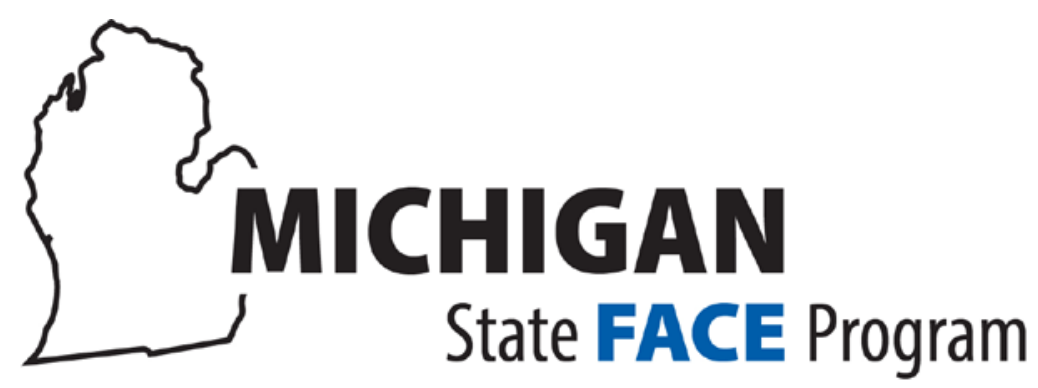

Fatality Assessment \& Control Evaluation

Michigan State University

Department of Medicine - Occupational and Environmental Medicine

909 Fee Road, 117 West Fee Hall • East Lansing, MI 48824

1-517-353-1846 - https://oem.msu.edu
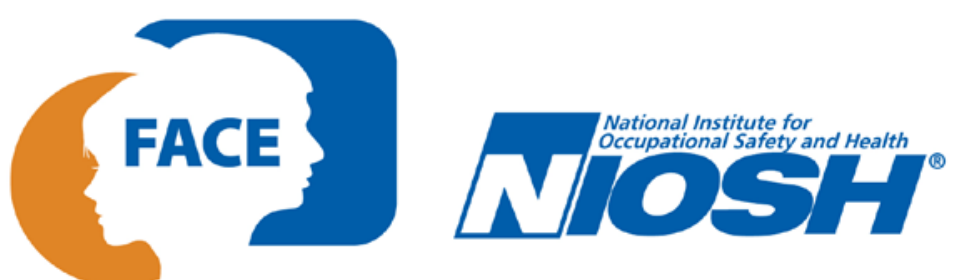

Michigan Fatality Assessment and Control Evaluation (FACE) Program

MIFACE (Michigan Fatality Assessment and Control Evaluation), Michigan State University (MSU) Occupational \& Environmental Medicine, 909 Fee Road, 117 West Fee Hall, East Lansing, Michigan 48824-1315; http://www.oem.msu.edu.

This information is for educational purposes only. This MIFACE report becomes public property upon publication and may be printed verbatim with credit to MSU. Reprinting cannot be used to endorse or advertise a commercial product or company. All rights reserved. MSU is an affirmative-action, equal opportunity employer. 


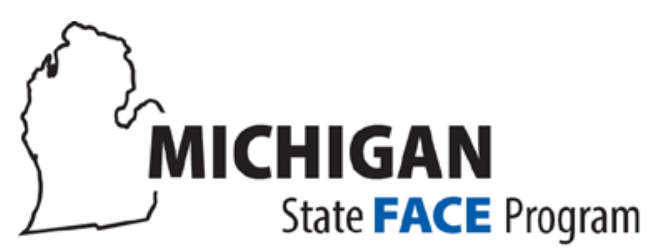

Fatality Assessment \& Control Evaluation

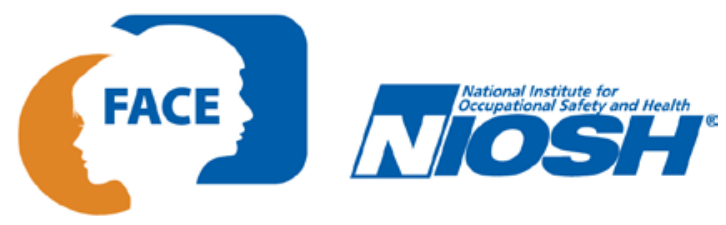

Michigan State University

Department of Medicine - Occupational and Environmental Medicine

909 Fee Road, 117 West Fee Hall • East Lansing, Ml 48824 • 1-517-353-1846 • https://oem.msu.edu

\section{SUMMARY}

In fall 2017 a male construction foreman/carpenter in his 40s died from complications of the injuries sustained in a 13foot fall from a metal pole barn roof. The crew had completed the installation of the plywood and felt for the 4/12 pitch roof. Some metal sheeting on one side of the roof had been installed. According to one coworker at the scene, when the crew arrived at the site, it was sprinkling. The decedent decided to build a platform on the side of the roof that had the metal sheets installed. The decedent was accessing the roof from a lift that was positioned so he could step from the lift to the roof. He was not wearing fall protection. The decedent was holding onto a sheet of plywood as he stepped from the lift to the roof, to hand the plywood to a coworker who had accessed the roof using a 25-foot ladder. The decedent took a few steps backward and may have stepped on the wet metal sheeting. He slipped and fell approximately 13 feet from the roof edge to the packed dirt below. Another firm's employee at the site called the decedent's employer; his employer called for emergency response. The decedent was taken to a local hospital where he died from complications of the fall approximately one month later.

\section{INTRODUCTION}

In fall 2017 a male construction foreman/carpenter in his 40s died from complications of the injuries sustained in a 13foot fall from a metal pole barn roof. MIFACE learned of this death from the MIOSHA fatality reporting system. MIFACE personnel contacted the firm owner, who agreed to be interviewed at the firm's headquarters. MIFACE reviewed the death certificate, medical examiner's report and the MIOSHA compliance officer file during the writing of this report. Pictures used in the report are courtesy of the MIOSHA compliance officer who was assigned to investigate this death.

\section{EMPLOYERS}

The employer, who had been in business for three years, was a general contractor for construction projects. The business managed construction work; $50 \%$ commercial and $50 \%$ residential construction. The firm employed five individuals, three of whom were hourly workers at the incident site performing roofing activities.

\section{WRITTEN SAFETY PROGRAMS and TRAINING}

The firm had a 110-page accident prevention program (APP) and a 78-page supervisor manual. The firm utilized an insurance-provided consultant and online resources for the safety program. Fall protection at heights and aerial lifts were addressed in the APP and supervisor manuals. The company owner told the MIFACE researcher that the APP was located in the company truck that was parked on-site. The company owner, who had on-the-job experience, was responsible for the safety program's administration.

The firm owner had a Certificate of Completion in February 2016 and March 2017 for continuing competency courses for license renewal, including 1-hr Building Code, 1-hr Safety, and 1-hr Legal Issues courses in 2016 from Michigan Builders License Continuing Competency.

The company owner indicated to the MIFACE researcher that the firm had a health and safety committee which met daily or every other day and that weekly safety meetings with employees were held. The decedent attended these meetings. There was a written disciplinary policy. The owner indicated to the MIFACE investigator that he had corrected employees for breaking the company safety policy. 


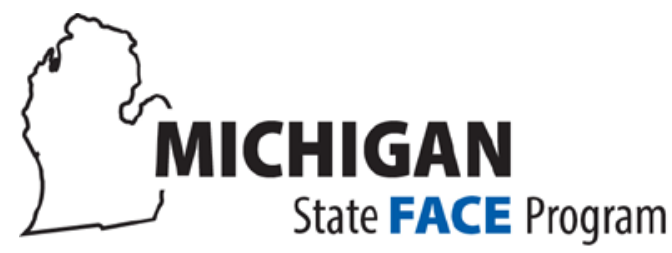

Fatality Assessment \& Control Evaluation

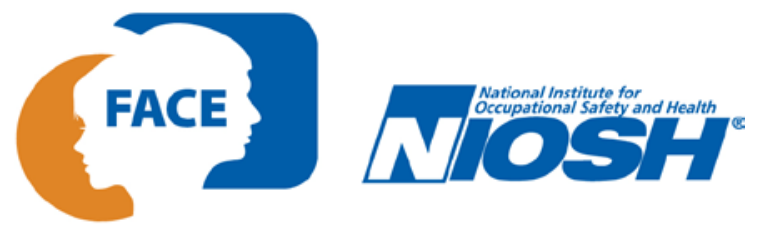

Michigan State University

Department of Medicine - Occupational and Environmental Medicine

909 Fee Road, 117 West Fee Hall • East Lansing, MI 48824 • 1-517-353-1846 • https://oem.msu.edu

The firm had a Safety Training Log signed by the decedent for Rough Terrain and Aerial Platforms. Lift training providers included both union training and the lift company manufacturer. Training was provided by videos and MIOSHA Consultation, Education and Training resources.

Discussing the safety program with MIFACE, the owner indicated he went out to construction sites two or three times per week for safety meetings and spoke with workers about what he observed. For example, the owner noted a damaged extension ladder and threw it away and then bought a new ladder and brought it to the worksite. The employer did not have an established safety training program but stated to the MIFACE investigator that he provided safety training to employees. They had weekly tool box talks about what work was to be done, and topics such as scaffolding, ladder safety, first aid, etc. According to the owner, the decedent had received training that specifically addressed the hazards associated with the fatality. MIOSHA determined through employee interviews that safety training regarding fall hazards was not provided by the employer, had not been included in safety talks or tool box talks, that the employees did not know that fall protection was available at the worksite and that employees had not been provided an opportunity to review/receive a copy of the firm's APP.

\section{WORKER INFORMATION}

The decedent was a full-time, hourly employee. He was a union carpenter but worked for a non-union company. The decedent was the main field supervisor for the employer. He had worked 20+ years for a previous contractor and had 15+ years of experience as a safety supervisor. He had been employed with the firm for 4 years. His normal work shift was 7:00 a.m. - 4:00 p.m. He was the foreman at the jobsite and was responsible for ensuring company safety procedures were followed.

The decedent had been assigned as the safety coordinator for the company. He ensured new employee training and was responsible for enforcement of the company's APP.

The employer indicated to the MIFACE researcher that decedent had received training and was certified to operate the lift involved in the incident.

\section{INCIDENT SCENE}

A friend of the employer wanted a pole barn to be built to be used as protected storage for various pieces of equipment and other items. The friend provided specifications for use for the building and asked if the decedent's employer would design it. After designing the building and given an "ok" for the truss design by the building owner, the decedent's employer began the building process. The decedent had been at the building site for the entire two months of construction (Figure 1).

The type of lift was unclear: MIOSHA described the lift as a

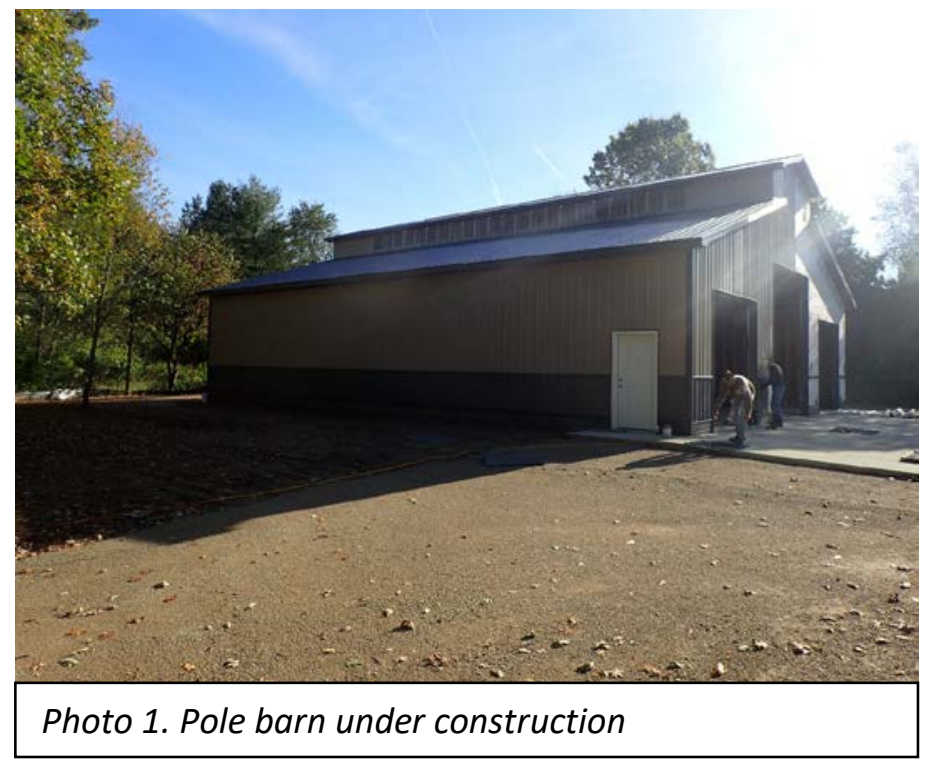
scissor lift and the owner described the lift as a telescopic boom lift when speaking with the MIFACE researcher. There was no police response for this incident to confirm the type of lift utilized by the decedent to access the roof. Another 


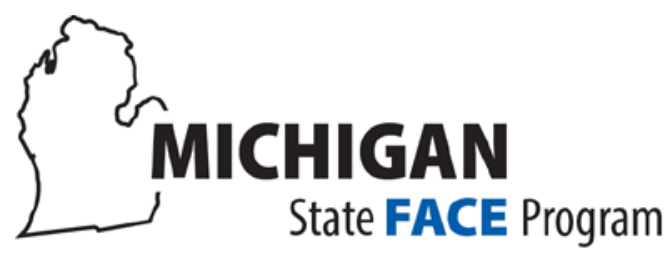

Fatality Assessment \& Control Evaluation

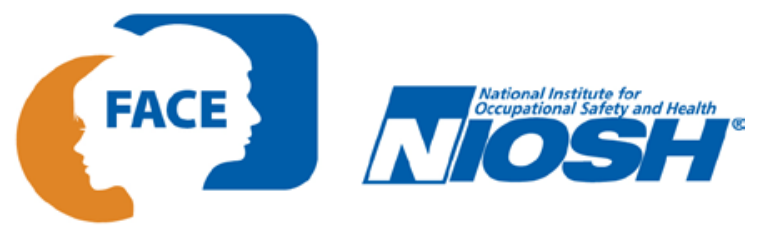

Michigan State University

Department of Medicine - Occupational and Environmental Medicine

909 Fee Road, 117 West Fee Hall • East Lansing, MI 48824 • 1-517-353-1846 • https://oem.msu.edu

contractor, who used the lift to paint the friend's home, had not retrieved the lift so the decedent used the lift to gain access to the pole building roof.

\section{WEATHER}

Weather Underground was utilized to check the weather conditions on the day of the incident. The weather on the day of the incident was approximately 60 degrees Fahrenheit, 90\% humidity, with northeast winds at $12 \mathrm{mph}$ and cloudy skies. It had rained 0.06 " of an inch in the very early morning hours, had a period of cloudy weather, then fog for $2 \frac{1}{2}$ hours, and then cloudy for approximately one-half hour after which time the decedent fell from the roof. [Weather Underground]

\section{INVESTIGATION}

The crew was installing a metal roof. Per the employer, the building roof was 60 feet long with a 5/12 slope; the MIOSHA compliance officer indicated the roof slope was 4/12. The distance from the roof edge to the dormer was 22 feet. The roof was completely sheeted with plywood and hi-density felt. Approximately one-half of the west side roof and one-half of the north side roof had metal sheeting installed. Approximately half of the screws had been placed and screwed in. The work plan was to wait until the very end of the installation to completely screw all the screws in the holes that had been drilled.

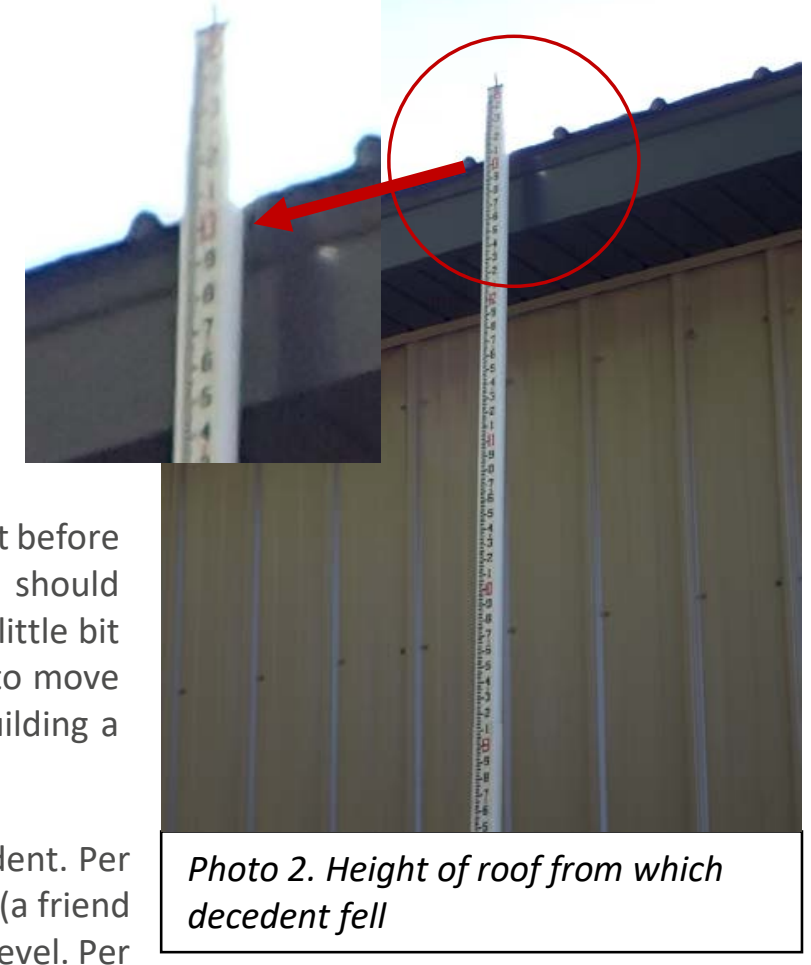

The owner stated that safety issues for the job were discussed the night before the incident; the crew was informed that if it was raining, they should postpone the roof work. Per coworker statements it was sprinkling a little bit and per the owner, it was misty. Coworkers indicated that they had to move the metal into the middle of the roof and that the decedent was building a "platform" on the roof.

It is unclear how the workers were positioned at the time of the incident. Per the owner, only the decedent was at the roof level; all other workers (a friend of another roofer and a company employee) were working at ground level. Per

decedent fell

MIOSHA interview statements, Coworker 1 was drilling metal sheeting on the roof out of sight of the incident area. Coworker 2 used a 25-foot ladder to access the roof; he was there to assist the decedent transport the 4-foot by 8-foot sheet of plywood the decedent was bringing up to the roof with the lift.

The employer told the MIFACE interviewer that the decedent was wearing tennis shoes. The decedent positioned the lift so he could step off of the platform onto the roof. The decedent stepped onto the roof and was standing on/near the section of the already metal sheeted roof while his coworker was standing on the felt section. The coworker indicated that the decedent took several steps backward, and then he slipped and fell approximately 13 feet from the roof onto packed dirt (See Photo 2). The decedent and both of his coworkers working on the roof were not wearing fall protection; per the MIFACE interview, the owner indicated there were three harnesses in the construction trailer. MIOSHA interviews with workers several weeks later who were at the scene at the time of the incident indicated that there were no anchor points provided on the roof for attachments for fall protection. 


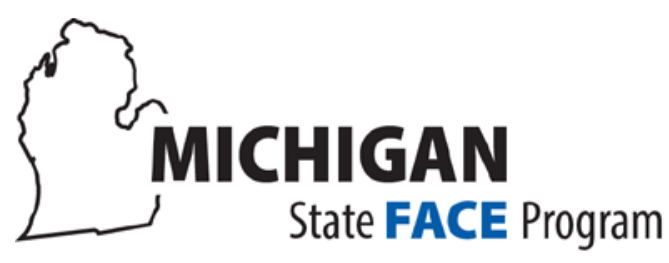

Fatality Assessment \& Control Evaluation

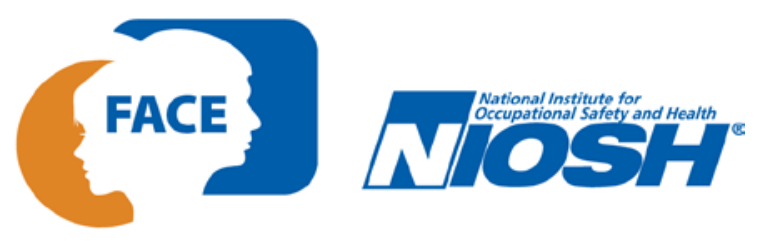

Michigan State University

Department of Medicine - Occupational and Environmental Medicine

909 Fee Road, 117 West Fee Hall • East Lansing, MI 48824 • 1-517-353-1846 • https://oem.msu.edu

Coworker 2 told Coworker 1 that the decedent fell from the roof; both coworkers climbed down the ladder and ran to the decedent's location. Another employer had two excavator operators in the vicinity working on another task who witnessed the decedent on the ground. One of the two excavator operators contacted the decedent's employer, who called for emergency response.

The decedent was transported to a nearby hospital. Approximately one month after the incident, he experienced medical complications relating to the injuries sustained by the fall causing his death.

The company owner brought in another employee to install the metal roof panels. This employee was not assigned fall protection and approximately one week later, also fell from the roof requiring hospitalization.

\section{MIOSHA Citations}

MIOSHA Construction Safety and Health Division issued the following Serious citations to the employer at the conclusion of its investigation.

SERIOUS: FALL PROTECTION, PART 45, REF 408.44502, RULE 1926.501(b)(10): Except as otherwise provided in paragraph (b) of this section, each employee engaged in roofing activities on low-slope roofs, with unprotected sides and edges 6 feet $(1.8 \mathrm{~m})$ or more above lower levels shall be protected from falling by guardrail systems, safety net systems, personal fall arrest systems, or a combination of warning line system and guardrail system, warning line system and safety net system, or warning line system and personal fall arrest system, or warning line system and safety monitoring system. Or, on roofs 50 -feet $(15.25 \mathrm{~m}$ ) or less in width (see Appendix A to subpart M of this part), the use of a safety monitoring system alone [i.e. without the warning line system] is permitted.

Employee exposed to falls of approximately 11 to 13 feet from a 4/12 roof pitch without the use of fall protection.

\section{Firm Remediation}

The firm took the following remedial steps to prevent a re-occurrence of a similar situation:

1. Employees who do not follow the firm's safety rules are subject to immediate termination.

2. New employees are required to sign a sheet indicating they understand the safety rules.

3. Most work is now subcontracted. Subcontractor contract language includes: requiring proof of a subcontractor's safety program, a written job safety analysis (JSA) developed by the subcontractor, and the firm must meet with the subcontractor to review the JSA prior to the subcontractor having access to the worksite.

4. Firm employees and relevant subcontractors meet one time/month to view online safety videos.

\section{CAUSE OF DEATH}

The death certificate listed the cause of death as complications of blunt force injuries to the torso. Post-mortem toxicological tests identified medications consistent with his hospitalization and were determined to be non-contributory to his death. 


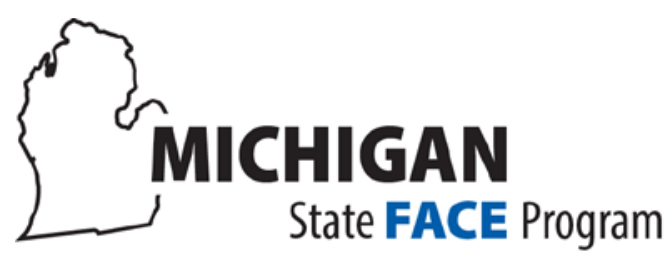

Fatality Assessment \& Control Evaluation

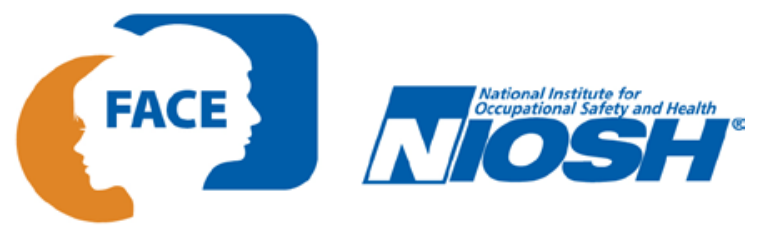

Michigan State University

Department of Medicine - Occupational and Environmental Medicine

909 Fee Road, 117 West Fee Hall • East Lansing, MI 48824 • 1-517-353-1846 • https://oem.msu.edu

\section{CONTRIBUTING FACTORS}

Occupational injuries and fatalities are often the result of one or more contributing factors or key events in a larger sequence of events that ultimately result in the injury or fatality. The following hazards were identified as key contributing factors in this incident:

- Did not wear fall protection

- Did not take work/environmental conditions into account

o Stepped from lift to roof holding OSB board during $12 \mathrm{mph}$ winds

o Metal roof was wet

- Safety program not implemented and enforced

\section{RECOMMENDATIONS/DISCUSSION}

Recommendation \#1: Employers should ensure that at least one of the following is used whenever employees are exposed to a fall of 6 feet or more above a lower level: Guardrail Systems; Safety Net Systems; Personal Fall Arrest Systems.

Discussion: If the decedent was utilizing a boom-supported elevating work platform, he was required to follow MIOSHA Construction Safety Standard, Part 32- Aerial Work Platforms when elevating to the roof edge. Per Rule 3214 of Part 32: “(4) An employer shall not allow employees to exit an elevated aerial work platform, except where elevated work areas are inaccessible or hazardous to reach. Employees may exit the platform with the knowledge and consent of the employer. When employees exit to unguarded work areas, fall protection shall be provided and used as required in construction safety standard Part 45. "Fall Protection," R 408.44501 to R 408.44502. Per the MIFACE interview with the employer, the employer indicated he would not have given his permission for the decedent to leave the work platform. The decedent had not secured himself to the lift as required by Part 32, Rule 3214 (1) requires an occupant of a boom-supported elevating work platform to utilize a fall arrest system only when the aerial lift is designed to withstand the vertical and lateral loads caused by an arrested fall. Rule 3214 (2) states: "An employee may use a body belt with a restraint device with the lanyard and the anchor arranged so that the employee is not exposed to any fall distance. An employee shall use a restraint device where when the aerial lift cannot withstand the vertical and lateral loads imposed by an arrested fall."

If the decedent was using a manually propelled elevating work platform or a self-propelled elevating work platform to elevate to roof level, the fall protection requirements of Part 32 would not apply. When the decedent stepped from the aerial lift to the roof, he was required to comply with MIOSHA Construction Safety Standard Part 45, Fall Protection because he was exposed to a fall of 6 feet or more above a lower level. The decedent should have been protected by a personal fall protection system which provided protection from falling (personal fall restraint (PFR) or to safely arrest his fall (personal fall arrest (PFA)). Both systems use anchorages, connectors, lanyards, and body harnesses.

\section{Recommendation \#2: Employers should ensure that established safety procedures are implemented and enforced on the worksite.}

Discussion: The firm's safety manual stated: "The name of company Construction policy is stringent regarding fall protection. If you disregard any fall protection policy, it will be grounds for immediate dismissal." The safety manual highlighted work practices for elevated work such as wearing safety belts, harnesses or lanyards, the use of proper lifelines, the securing of lifelines to two different anchors, the assurance of proper anchor construction and placement, etc. 


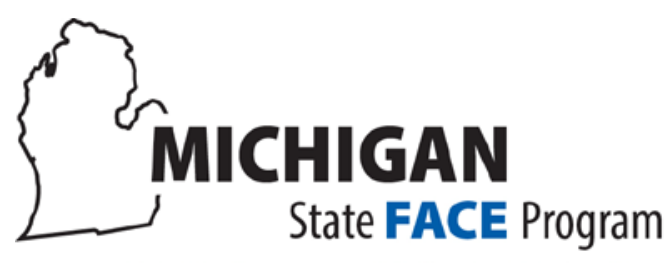

Fatality Assessment \& Control Evaluation

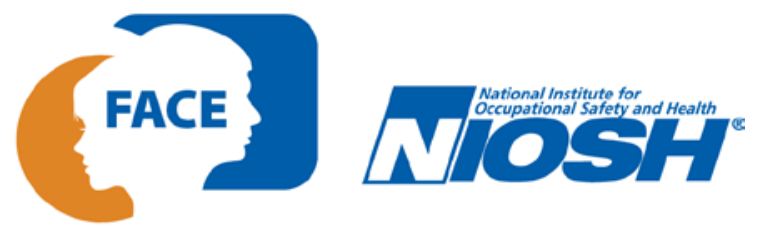

Michigan State University

Department of Medicine - Occupational and Environmental Medicine

909 Fee Road, 117 West Fee Hall • East Lansing, MI 48824 • 1-517-353-1846 • https://oem.msu.edu

The firm owner was present the day prior to the incident when workers were working on the roof without fall protection. Both the decedent, who was the "safety guy", and the owner did not enforce the use of fall protection at the site. A safety program is effective only when individuals receive the appropriate training (per MIOSHA employee interviews, they had not) and it is enforced. Harnesses were present in the construction trailer, but were not utilized.

There are many methods to implement safety procedures and practices for fall protection. A project pre-plan could include a signature page which all employees on a job have to sign prior to commencing with the work. The signature page would verify that all affected employees are aware of their safety responsibilities and would give them the opportunity to ask questions and clarify any misunderstandings. Initial and periodic safety inspections and audits of the workplace can be performed by management personnel to ensure that job site supervisors identify safety hazards or unsafe acts as they occur so that corrective action can be taken immediately. Corrective action might include a form of discipline for unsafe acts or behavior, as well as recognition or reward for safe acts and behavior. Had these methods been used at this jobsite, the employees would most likely have worn the required fall protection and this incident would have been avoided. Employers can enhance worker compliance with safe work practices through programs of task-specific training, supervision, recognition, and progressive disciplinary measures.

\section{Recommendation \#3: Employers should ensure employees conduct a worksite hazard assessment, which includes environmental conditions, prior to performing work.}

Discussion: It is unknown if the workers at the scene performed a hazard assessment that included environmental conditions. It is unknown if the decedent identified the possible hazards of a wet roof and 12-mph winds, particularly while holding a piece of OSB. The board may have acted like a sail, catching the wind and contributing to the decedent's loss of balance. The decedent was the "safety guy" on the site and responsible for ensuring work was performed safely.

\section{ADDITIONAL RESOURCES}

- MIOSHA Consultation, Education and Training Fact Sheet: $\underline{\text { Highlights of the Fall Protection Standard }}$

- State and NIOSH Fatality Assessment and Control Evaluation (FACE) Reports

o https://www.cdc.gov/niosh/face/stateface/ky/13KY042.html

0 https://www.cdc.gov/niosh/face/stateface/nj/09NJ099.html

o https://www.cdc.gov/niosh/face/stateface/ca/10CA003.html

o https://www.cdc.gov/niosh/face/In-house/full201202.html

o https://www.cdc.gov/niosh/face/In-house/full9509.html

- OSHA Fact Sheet Reducing Falls During Residential Construction: Re-Roofing https://www.osha.gov/Publications/reducing-falls-during-residential-construction-re-roofing.html

- OSHA Fact Sheet Reducing Falls During Residential Construction: Sheathing https://www.osha.gov/Publications/reducing-falls-during-residential-construction-roof-sheathing.html

- OSHA Interpretation: Use of tennis shoes on steep roofs. https://www.osha.gov/lawsregs/standardinterpretations/2004-05-28 


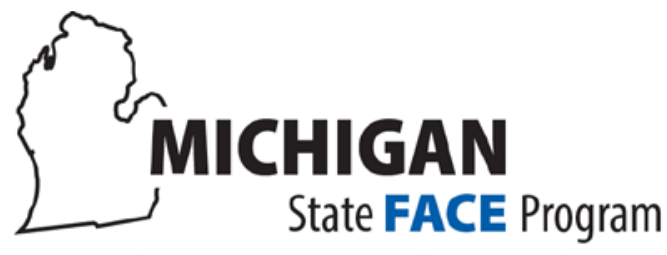

Fatality Assessment \& Control Evaluation

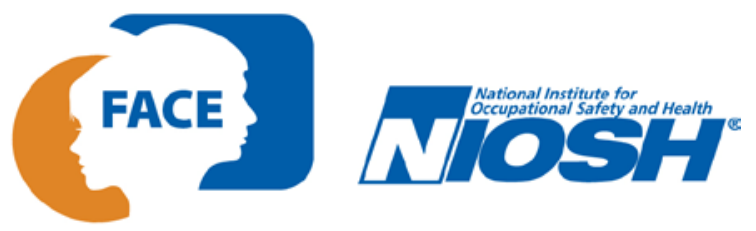

Michigan State University

Department of Medicine - Occupational and Environmental Medicine

909 Fee Road, 117 West Fee Hall • East Lansing, MI 48824 • 1-517-353-1846 • https://oem.msu.edu

\section{DISCLAIMER}

Mention of any company or product does not constitute endorsement by the Michigan FACE program or the National Institute for Occupational Safety and Health (NIOSH). In addition, citations to websites external to NIOSH do not constitute $\mathrm{NIOSH}$ endorsement of the sponsoring organizations or their programs or products. Furthermore, NIOSH is not responsible for the content of these websites. All web addresses referenced in this document were accessible as of the publication date.

\section{REFERENCES}

Weather Underground [2015]. Weather history for nearby weather station. The Weather Channel Interactive, Inc.

MIOSHA standards may be found at and downloaded from the MIOSHA, Michigan Department of Licensing and Regulatory Affairs (LARA) website at: www.michigan.gov/mioshastandards. MIOSHA standards are available for a fee by writing to: Michigan Department of Licensing and Regulatory Affairs, MIOSHA Standards Section, P.O. Box 30643, Lansing, Michigan 48909-8143 or calling 517-284-7740.

- Construction Safety Standard, Part 45. Fall Protection.

- Construction Safety Standard, Part 32. Aerial Platforms

\section{ACKNOWLEDGEMEMENT}

The Michigan FACE Program would like to acknowledge the company owner for providing assistance and information for this investigation. 